years. The inception and development of broadcasting, and later of television, resulting from the earlier introduction of the thermionic valve to industry, have revolutionised the scope of normal commercial telegraphic and telephonic communication. These developments have naturally been accompanied by the establishment of radio frequency research laboratories in all parts of the world, some of these being controlled by government administration, while others are assaciated with private enterprise. The issue of La Nature of September 15 is devoted to an illustrated account of several such radio research laboratories. Much space is devoted to the work of the French institutions, Le Laboratoire National de Radio-Electricite, Le Laboratoire du Comite Consultatif, Les Laboratoires de Recherches du "Materiel Téléphonique", and to the private laboratories engaged on television. In addition, however, the work of the Heinrich Hertz Institute and of M. von Ardenne in Berlin are described briefly; while attention is also devoted to the Philips Laboratories at Eindhoven, the Bell Telephone Laboratories in New York, the Italian Television Laboratory and that of the Baird Television Laboratory, the only English laboratory mentioned. Further articles deal with work in France in connexion with broadcasting, valve manufacture and research on the interference problem. The whole issue presents an interesting summary of the scope and position of research in the institutions enumerated.

\section{Solar Physics Observatory, Cambridge}

IN his twenty-third annual report to the Solar Physics Committee the Director of the Solar Physies Observatory, Cambridge, is able to point to a number of interesting results obtained from a particularly active year. To begin with, the 3 -ft. Common mirror has been refigured by Dr. Burch, who has developed a special new method of testing paraboloids in this connexion. The performance of the mirror is greatly improved, and it is hoped to improve the 10-in. secondary mirror used with this large mirror and so obtain really good definition with the 3 -ft. telescope. The year's work on stellar spectroscopy has been notable on account of special observations made during the eclipse of $\zeta$ Aurigæ and for the work on Nova Herculis. A very special effort was made, and altogether 284 spectra were secured on 137 nights between December 13, 1934, and July 31,1935 . This is a very fine performance for the climate of Great Britain, and was only made possible by enthusiastic team work by the staff and research workers at the Observatory. An item of interest is the attempt made by Drs. Redman and Bullard to determine the diameter of Antares by observing the brightness during an occultation by the moon. Unfortunately, the apparatus broke down at a critical point in the observation, but there appears to be nothing unworkable in the method, which is of extreme interest, and it is to be hoped that the experiment will be repeated at the next favourable occultation. The solar work has continued, perhaps the most noteworthy item being the accurate determination of the central intensity of the line at
$4227 \mathrm{~A}$. (due to $\mathrm{Ca}^{+}$) by Dr. Redman, the result being 2 per cent - possibly the lowest central intensity yet accurately measured. The Observatory has arranged to send an expedition to observe the total solar eclipse of June 19, 1936, the site chosen being in the island of Hokkaido. Finally, the work on meteorological physics has been continued, and the work on the $\mathrm{Fe}_{\Theta}+$ laboratory spectrum has been brought to a successful conclusion, 58 new multiple terms and 157 levels having been determined.

\section{Archæology in South-East Essex}

Local archæologies and local histories have a useful function which is seldom fulfilled satisfactorily. To write them successfully requires a nice perception of the balance between the foreground of local interest and the background of the general trend of history or cultural development. Of the importance of the detailed record of local finds there can, however, be no two opinions. The studies of East Anglian archæology which we owe to Sir Cyril Fox have demonstrated the almost kaleidoscopic changes in the generalised picture as the records of local finds are brought more and more into focus. An excellent example of a method of treatment of local antiquities, which may be followed to advantage, is afforded by "The Archæology of Rochford Hundred and SouthEast Essex" by Mr. William Pollitt (Southend-onSea Museum, Handbook No. 7, pp. 59 with 22 plates, $6 d$.$) , in which the author follows up a survey$ of the archæology of the district from pre-palæolithic down to and including Saxon times with a detailed list of the 'finds' in the area, classified according to period and arranged under parishes, the present location of each specimen being noted where known. The distinction to be drawn between south-east Essex and the central and north-western areas of the county on geographical lines is no less apparent in its archæology. For this reason, if for no other, the general background becomes of no little importance for the appreciation of the significance of the finds. Here, it will be found, fully adequate provision has been made for the needs of those who will use the handbook. A map, or series of maps, showing the localities in which the antiquities were found, would have been a useful addition to the ample and excellent illustrations.

\section{Shipbuilding by Welding}

Electric-ARc welding has now arrived at the stage where it is recognised as an important aid to shipbuilding, and its field is being extended so rapidly that there are few shipbuilders or repairers who do not now avail themselves of its use. With this statement, Messrs. N. M. Hunter, vice-president, and H. W. Townshend, associate member, opened a paper read to the North-East Coast Institution of Engineers and Shipbuilders on November 15. They deal with the subject descriptively, and explain the methods used in the fabrication of various parts of the hull structure. The amount of work now done by welding and the marked advantages gained in some instances testify to its growing importance. Welding the steel decks has, for example, produced 